\title{
MAKNA IMPLISIT DALAM FILM PURSUIT OF HAPPINESS KARYA GABRIELE MUCCINO
}

\author{
Dede Narawaty \\ Jurusan Bahasa Inggris, Fakultas Bahasa dan Seni \\ Universitas Indraprasta PGRI \\ Pos-el: dnarawaty@yahoo.com \\ Ponsel: 081806305714
}

\begin{abstract}
ABSTRAK
Tujuan penelitian ini adalah unuk menganalisis penggunaan makna implisit dalam film Pursuit of Happiness karya Gabriele Muccino. Selain itu, penulis berharap penonton dapat memamahami isi dari film itu. Metode yang digunakan untuk menganalisis novel ini adalah dengan menggunakan metode kualitatif yang memuat satu unsur yaitu intrinsik. Selain itu, penulis menggunakan pendekatan objektif dalam menyususn langkah kerjanya. Setelah penuis menganalisis Pursuit of Happiness melalui analisis makna implisit, simpulan adalah belum banyak terdapat makna implisist dalam Pursuit of Happiness.
\end{abstract}

Kata Kunci: semantik, perubahan makna, pergeseran makna, dialog antartokoh, teks, naratif, pembelajaran bahasa

\section{ABSTRACT}

The purpose of this study is to analyze the use of language in the film "Pursuit of Happiness" by Gabriele Muccino to express the implicit meaning. Besides, the writer hopes that the audience understands the content of the film. The method used to analyze the novel is by using qualitative method containing an intrinsic element. After the writer analyzes the movie "Pursuit of Happiness" through the analysis of implicit meaning, finally the writer can draw the conclusion that there are many implicit meanings in the film "Pursuit of Happiness".

Keywords: semantics, meaning change, meaning shift, characters dialogues, narrative texts, language learning

\section{PENDAHULUAN}




\section{Latar Belakang Masalah}

Bahasa merupakan komponen terpenting dalam kehidupan manusia, yaitu sebagai alat komunikasi, baik komunikasi antarindividu yang satu dengan yang lain maupun antarkelompok yang satu dengan kelompok yang lain. Interaksi dan segala macam kegiatan yang terjadi dalam kehidupan bermasyarakat dapat terjadi melalui proses berbahasa. Bahasa merupakan salah satu alat komunikasi baik secara lisan maupun tertulis. Komunikasi ini dapat terjadi apabila ada proses interaksi antarmanusia dalam kehidupan masyarakat. Manusia membutuhkan bahasa sebagai alat untuk menyampaikan ide, pikiran, dan gagasan kepada pihak lain dalam suatu masyarakat. Bahasa juga merupakan alat pengungkapan yang baik, yang dapat memberikan efek tertentu yang bukan saja menggambarkan objek, tetapi juga dapat melahirkan setepat-tepatnya apa yang dimaksudkan oleh penutur.

Berdasarkan hal tersebut, fungsi bahasa yang paling utama adalah sebagai sarana komunikasi. Setiap anggota masyarakat dan komunitas selalu terlibat dalam komunikasi bahasa, baik dia bertindak sebagai komunikator (pembicara atau penulis) maupun sebagai komunikan (mitra bicara, penyimak, pendengar, atau pembaca).

Komunikasi pada saat ini yang dipergunakan masyarakat dalam kehidupan sosialnya adalah komunikasi verbal. Secara garis besar sarana komunikasi verbal dibedakan menjadi dua macam, yaitu sarana komunikasi yang berupa bahasa lisan dan sarana komunikasi yang berupa bahasa tulis. Begitu pula wacana atau tuturan pun dibagi menjadi dua macam, yaitu wacana lisan dan wacana tulis.

Bahasa dipergunakan sebagai sarana komunikasi dalam menyampaikan pesan. Beberapa contohnya sarana komunikasi sebagai penyampaian pesan, pikiran dan gagasan. Penyampaian pesan, pikiran, atau gagasan di era modern ini melalui komunikasi verbal semakin beragam macamnya ada yang melaui novel, cerpen, puisi, dan film. Penyampaian pesan yang kompleks banyak dituangkan melalui sarana komunikasi bahasa tulisan karena begitu kompleks harus dijelaskan dengan kata-kata tetapi terkadang bahasa lisan juga sering terjadi komunikasi yang kompleks.

Penyampaian pesan melalui sarana komunikasi bahasa tulisan dan lisan mengharuskan mengerti akan apa yang disampaikan, agar tidak salah dalam memaknai dan mengartikan sesuatu. Penyampaian pesan, pikiran atau gagasan dapat disampaikan dengan berbagai jenis makna, yakni dalam setiap makna mempunyai pengertian yang berbeda-beda. Penggunaan makna dalam setiap penyampaian sesuatu secara tertulis dan tidak tertulis akan memberikan ciri dari setiap makna yang ingin diutarakan. Makna yang diutarakan tidak secara langsung masih banyak terjadi kesalahan dalam pemaknaanya dan pengertiaanya. Dalam pemaknaan disampaikan secara tidak langsung membutuhkan proses yang lebih mendalam unutuk mengerti apa yang disampaikan.

Mengartikan suatu makna bahasa menjadi sebuah tolak ukur mengertinya pembaca dengan apa yang ingin disampaikan. Hal itu akan sangat sulit untuk mendapatkan hasil yang ingin disampaikan penulis karena banyak perbedaan mulai dari bahasa, budaya dan kebiasaan dalam penggunaan makna bahasa. Oleh karena itu banyak terjadi kesalahan dalam mengartikan makna yang berbeda bahasa, budaya serta kebiasaan.

Makna bahasa yang tidak disampaikan secara langsung adalah makna implisit. Samuel dan Kiefer (dalam Aminuddin, 1985: 92), mengemukakan adanya ungkapan reading the lines, yakni membaca untuk memahami makna yang tersurat dan ungkapan reading between the lines, yaitu membaca untuk memahami makna yang implisit. Jadi, makna dapat dibedakan antara makna yang tersurat dan makna yang tersirat. 
Dalam setiap komunikasi verbal baik tertulis maupun tidak tertulis hampir selalu terdapat makna implisit. Makna yang disampaikan secara implisit akan sulit untuk mendapatkan hasil yang diinginkan dan sesuai dengan penulis. Dengan perbedaaan dan keterbatasan bahasa, baik bahasa sendiri maupun bahasa asing pemaknaan secara implisitdan akan berbeda-beda pengertiannya. Idealnya dalam setiap penyampaian pesan, komunikan dapat mengerti apa yang disampaikan komunikator atau penulis walaupun banyak perbedaan dan kekurangan pesan yang disampaikan secara baik dan benar. Larson (1984: 34) menyatakan bahwa makna implisit merupakan makna yang tidak ditampilkan tetapi merupakan bagian dari pembicaraan atau maksud yang ingin disampaikan penutur. Di dalam proses memahami makna implisit ini, penanggap tutur terkadang harus berusaha keras untuk tiba pada tafsiran yang tepat antara lain dengan melalui pembayangan atau penafsiran. Penanggap harus mengetahui hal tertentu yang menjadi acuan, situasi dan konteks. Pengetahuan konteks akan sangat membantu penanggap untuk mendapat tafsiran yang tepat. Oleh karena itu, dalam setiap mengartikan makna implisit mengaharuskan ketelitian dan kesungguhan dalam membaca atau menyimak.

Cerita film ini dimulai pada tahun 1981 di San Francisco, California. Linda dan Chris Gardner hidup di sebuah apartemen kecil bersama anak mereka yang berusia 5 tahun, Christopher. Chris adalah seorang salesman yang menghabiskan seluruh tabungan keluarga untuk membeli franchise untuk menjual scanner tulang (Bone Density Scanner) portable. Scanner ini memang mampu menghasilkan gambar lebih baik dari X-ray, tetapi kebanyakan dokter yang ditemui Chris beranggapan bahwa harganya terlalu mahal. Linda, istrinya, bekerja sebagai buruh di sebuah laundry. Keluarga kecil ini mulai terpecah ketika mereka menyadari bahwa mereka tak mampu membayar sewa rumah dan tagihan-tagihan yang semakin menumpuk. Keadaan diperparah oleh kebiasaan Chris yang memarkir mobilnya sembarangan. Karena tak mampu membayar surat tilang, mobil Chris akhirnya disita. Puncaknya, Linda pergi meninggalkan Chris dan pergi ke New York City. Awalnya ia hendak membawa serta Christopher, tetapi urung atas permintaan Chris.

Dalam keadaan putus asa, Chris tak sengaja berjumpa dengan seseorang yang membawa Ferari warna merah. Chris bertanya kepada orang itu, pekerjaan apa yang ia lakukan sehingga mampu membeli mobil mewah? Orang tersebut menjawab bahwa ia adalah seorang pialang saham. Sejak saat itu Chris memutuskan untuk berkarir sebagai pialang saham.

Chris menerima tawaran magang tanpa dibayar di sebuah perusahaan pialang Dean Witter Reynolds yang menjanjikan pekerjaan bagi peserta magang terbaik. Dalam masa magang yang tak dibayar itu, Chris mulai kehabisan uang. Akhirnya ia diusir dari rumah sewanya dan menjadi tuna wisma. Selama beberapa hari ia tidur di tempat-tempat umum, namun kemudian ia memutuskan untuk tidur di rumah singgah Glide Memorial Chruch. Karena keterbatasan tempat, mereka harus mengantri untuk mendapatkan kamar. Kadang mereka berhasil, kadang gagal dan terpaksa tidur diluar. Kemiskinan dan ke-tunawisma-an ini semakin mendorong tekad Chris untuk menjalankan tugas dengan giat dan mendapatkan pekerjaan di Dean Witter Reynolds.

Di akhir cerita, Chris berhasil menjadi peserta terbaik dan diterima bekerja di sana. Beberapa tahun kemudian, ia mendirikan perusahaan pialang sendiri, Gardner Rich. Pada tahun 2006, ia menjual sebagian kecil sahamnya dan berhasil mendapatkan jutaan dolar dari penjualan itu. 
Berdasarkan uraian dan deskripsi diatas penulis membatasi pembahasan hanya makna imlisit dalam film Pursuit of Happiness dengan pertimbangan bahwa makna bahasa secara implisit.

\section{Rumusan Masalah}

Berdasarkan latar belakang, rumusan masalah adalah sebagai berikut :

1. Apasajakah makna implisit referensial yang diterkandung dalam film Pursuit of Happiness?

2. Apakah Makna implisit organisasional yang terkandung di dalam Film Pursuit of Happiness?

3. Apakah Makna implisit situasional yang terkandung di dalam Film Pursuit of Happiness ?

\section{Tujuan Penelitian}

Penelitian ini bertujuan untuk memperoleh deskripsi data dan informasi yang jelas tentang pengertian makna implisit dan menegtahui apasaja makna implisit di sebuah film terutama film "Pursuit of Happiness", dan untuk mengetahui makna implisit referensial, makna implisit organisasional dan makna implisit situasional yang ada di novel, juga untuk mengetahui bagaimana ketiga makna tersebut diterjemahkan ke dalam bahasa Indonesia serta untuk mengetahui penyesuaian yang diperlukan oleh penerjemah dalam menyampaikan makna-makna implisit tadi ke dalam bahasa Indonesia sebagai bahasa sasarannya sehingga dapat ditarik simpulan secara umum mengenai penerjemahan makna implisit dalam film tersebut.

\section{Kegunaan Penelitian}

\section{Kegunaan Teoretis}

Penelitian ini diharapkan dapat memberikan masukan yang cukup relevan sehingga dapat dijadikan bahan kajian materi perkuliahan di Program Studi Pendidikan Bahasa Inggris khususnya mata kuliah Linguistik.

\section{Kegunaan Praktis}

a. bagi pembaca

Dalam hal ini kegunaan praktis yang menambah pengetahuan dan masukan guna.

b. bagi penulis

Dapat dijadikan sebagai bahan masukan untuk mengadakan penelitian terkait dengan permasalahan ini atau penelitian lanjutan.

\section{Lanadasan Teori}

\section{Film}

Films are cultural artifacts created by specific cultures, which reflect those cultures, and, in turn, affect them. Film is considered to be an important art form, a source of popular entertainment and a powerful method for educating or indoctrinating - citizens. The visual elements of cinema give motion pictures a universal power of communication. Some films have become popular worldwide attractions by using dubbing or subtitles that translate the dialogue. http://en.wikipedia.org/wiki/Film (diakses 18 Juni 2014).

Film adalah gambar-hidup, juga sering disebut movie. Film, secara kolektif, sering disebut sinema. Sinema itu sendiri bersumber dari kata kinematik atau gerak. Film juga sebenarnya merupakan lapisan-lapisan cairan selulosa, biasa dikenal di dunia para sineas 
sebagai seluloid. Pengertian secara harafiah film (sinema) adalah Cinemathographie yang berasal dari Cinema + tho $=$ phytos $($ cahaya $)+$ graphie $=$ grhap $($ tulisan $=$ gambar $=$ citra $)$, jadi pengertiannya adalah melukis gerak dengan cahaya. Agar kita dapat melukis gerak dengan cahaya, kita harus menggunakan alat khusus, yang biasa kita sebut dengan kamera. http://id.wikipedia.org/wiki/Film (diakses 18 Juni 2014).

Film dihasilkan dengan rekaman dari orang dan benda (termasuk fantasi dan figur palsu) dengan kamera, dan/atau oleh animasi. Kamera film menggunakan pita seluloid (atau sejenisnya, sesuai perkembangan teknologi). Butiran silver halida yang menempel pada pita ini sangat sensitif terhadap cahaya. Saat proses cuci film, silver halida yang telah terekspos cahaya dengan ukuran yang tepat akan menghitam, sedangkan yang kurang atau sama sekali tidak terekspos akan tanggal dan larut bersama cairan pengembang (developer). 9DA, \$\$6\# : $<A 76: 4 \quad: \angle \$ 2 C$

\section{Makna}

Ada 3 hal yang ingin dijelaskan oleh filsuf dan linguist sehubungan dengan usaha menjelaskan makna. Ketiga hal itu, ialah (a) menjelaskan makna kata secara ilmiah, (b) mendeskripsikan mekna kalimat secara ilmiah, dan (c) menjelaskan proses komunikasi (Kempson, 1977: 11).

Ada hubungan antara nama dan pengertian; apabila seorang mendengar kata ia tentu membayangkan suatu benda ia akan segera mengatakan benda tersebut. Inilah hubungan timbale balik antara bunyi dan pengertian, dan inilah makna kata tersebut. (Ulmann, 1972: 52).

Lyons (1981: 136) berpendapat "Meanings are ideas or concepts which can be transferred from the mind of the hearer by embodying them as they were, in the form of one language or another." Jadi makna adalah ide atau gagasan yang dapat dialihkan dari pikiran pendengar dengan mewujudkan makna tersebut sebagaimana mestinya dalam satu bentuk bahasa atau lainnya.

Yang dimaksud dengan makna adalah

“...maksud pembicara, pengaruh satuan bahasa dalam pemahaman persepsi atau perilaku manusia atau kelompok manusia, hubungan dalam arti kesepadanan atau ketidaOksepadanan antara bahasa dan alam di luar bahasa atau antara ujaran dan semua hal yang ditunjuknya, atau cara menggunakan lambang-lambang bahasa." (Kridalaksana, 1993: 132)

Di lain pihak Hurford (1983: 3) lebih cenderung mengartikan makna sebagai maksud penutur yang dituangkan ke dalam kata-kata atau kalimat yang berbeda. Untuk itulah Hurford mendefinisikan makna ke dalam dua bagian:

1) Makna penutur (speaker meaning), yaitu makna yang diinginkan penutur (atau yang ingin disampaikan oleh penutur).

2) Makna kalimat atau makna kata (sentence meaning / word meaning) adalah makna yang terkandung dalam kalimat (atau kata).

Dalam pemakaian sehari-hari kata "makna" digunakan dalam berbagai bidang maupun konteks pemakaian. Makna juga disejajarkan pengertiannya dengan arti, gagasan, konsep, pernyataan, pesan, informasi, firasat, isi dan pikiran (Hutford, 1985: 50).

Aminuddin juga menjelaskan bahwa makna yang terdapat pada kata ternyata memiliki hubungan erat dengan: 
1. Sistem sosial budaya maupun realitas luar yang diacu.

2. Pemakai dan penutur.

3. Konteks sosial situasional dalam pemakaian.

Ogden dan Richards (1972: 186 -187) menyimpulkan, makna adalah sebagai berikut:

a. Suatu perbendaharaan yang intrinsik;

b. Hubungan dengan benda - benda yang lain yang unik, yang tak dapat dianalisis;

c. Kata lain tentang suatu kata yang terdapat di dalam kamus;

d. Konotasi kata;

e. Suatu esensi;

f. Suatu aktivitas yang diproyeksikan ke dalam suatu objek

1. suatu peristiwa yang dimaksud,

2. keinginan, dan

3. tempat sesuatu di dalam suatu sistem

g. Konsekuensi praktis dari suatu benda dalam pengalaman kita mendatang;

h. Konsesuensi yang teoritis yang terkandung di dalam sebuah pernyataan.

\section{Makna Implisit}

Makna implisit adalah makna universal yang disembunyikan oleh bahasa.Konsep makna ini bersifat konotatif (kias) sebagai representasi dari bahasa emotif.

Larson (1984: 34) menyatakan bahwa makna implisit merupakan makna yang tidak ditampilkan tetapi merupakan bagian dari pembicaraan atau maksud yang ingin disampaikan penutur. Di dalam proses memahami makna implisit ini, penanggap tutur terkadang harus berusaha keras untuk tiba pada tafsiran yang tepat antara lain dengan melalui pembayangan atau penafsiran. Penanggap harus mengetahui hal tertentu yang menjadi acuan, situasi dan konteks. Pengetahuan konteks akan sangat membantu penanggap untuk mendapat tafsiran yang tepat.

Samuel dan Kiefer dalam Aminuddin (1985: 92) mengemukakan adanya ungkapan reading the lines, yakni membaca untuk memahami makna yang tersurat dan ungkapan reading between the lines, yaitu membaca untuk memahami makna yang implisit. Jadi, makna dapat dibedakan antara makna yang tersurat dan makna yang tersirat.

Masih menurut Aminuddin (1985: 50) agar seorang penanggap dapat mencapai tafsiran yang tepat, dalam proses penafsirannya makna harus diperhatikan keterkaitannya dengan hal-hal sebagai berikut.

1. Ciri-ciri atau unsur internal kebahasaan.

2. Sistem sosial budaya yang melatari.

3. Pemakai, baik sebagai penutur atau penanggap tutur.

4. Ciri informasi dan ragam tuturan yang disampaikan.

\section{Makna Referensial}

Keberadaan referen dalam menginterpretasikan makna sangatlah penting. Makna akan sulit untuk dimengerti apabila referennya tidak diketahui. Gambaran makna yang dihasilkan oleh elemen kebahasaan yang berupa kata, kalimat maupun elemen lainnya sehubungan dengan unsur luar bahasa baik itu berupa realitas maupun pengalaman disebut referen (Aminuddin, 1985: 88).

Kridalaksana (1993: 186) mengatakan bahwa referen adalah unsur luar bahasa yang ditunjuk oleh unsur bahasa. Yang dimaksud dengan unsur bahasa di sini diantaranya kata 
atau kalimat. Makna referensial, menurut Kridalaksana, adalah makna unsur bahasa yang sangat dekat hubungannya dengan dunia di luar bahasa (objek atau gagasan), dan yang dapat dijelaskan oleh analisis komponen (1993 : 199). Dengan kata lain makna ini mengacu langsung pada benda, kejadian, atribut, atau relasi tertentu yang dapat dilihat atau dibayangkan yang merupakan isi informasi atau sesuatu yang dikomunikasikan.

Halliday dan Hasan (1976: 37) mengemukakan bahwa referen dalam suatu teks bisa bersifat eksoforik, yaitu yang mengacu pada hal-hal di luar konteks, ataupun endoforik yaitu yang referennya terdapat dalam konteks itu sendiri. Referen endoforik terbagi dalam anaforik, yang mengacu pada referen yang telah disebutkan dan kataforik yaitu yang mengacu pada konteks yang mengikutinya.

Kemudian Halliday dan Hasan mengelompokkan referen ke dalam tiga jenis, yaitu:

1. referen personal, yaitu referen yang terdapat pada kategori persona,

2. referen demonstratif, yaitu referen yang terdapat pada penunjukan lokasi atau tempat, dan

3. referen komparatif adalah referen tidak langsung yang terdapat pada pemakaian ciriciri atau kesamaan sesuatu.

Kemiripan bersifat referen. Sebuah benda tidak dapat dikatakan "mirip" saja, tetapi harus dikatakan "mirip dengan sesuatu". Jadi perbandingan antara dua hal yang mirip adalah salah satu bentuk referen. Referen yang seperti ini disebut referen komparatif. Selanjutnya dalam pembahasan mengenai referen komparatif, Halliday dan Hasan (1976 : 76-80) membagi referen kompatif menjadi dua, yaitu:

1. komparatif umum, yaitu referen yang mengekpresikan kemiripan antara benda. Dua buah benda dapat sama, serupa atau berbeda.

2. komparatif khusus, yaitu perbandingan antara benda dengan memperhatikan perbedaan kualitas atau kuantitas. Baik referen komparatif umum maupun referen komparatif khusus diekspresikan dalam konteks dengan menggunakan adjektif (same, equal, identical) atau adverbial (identically, differently). Untuk selengkapnya dapat dilihat pada struktur referen komparatif berikut ini.

\section{Referen Komparatif (Halliday dan Hasan, 1976 : 76)}

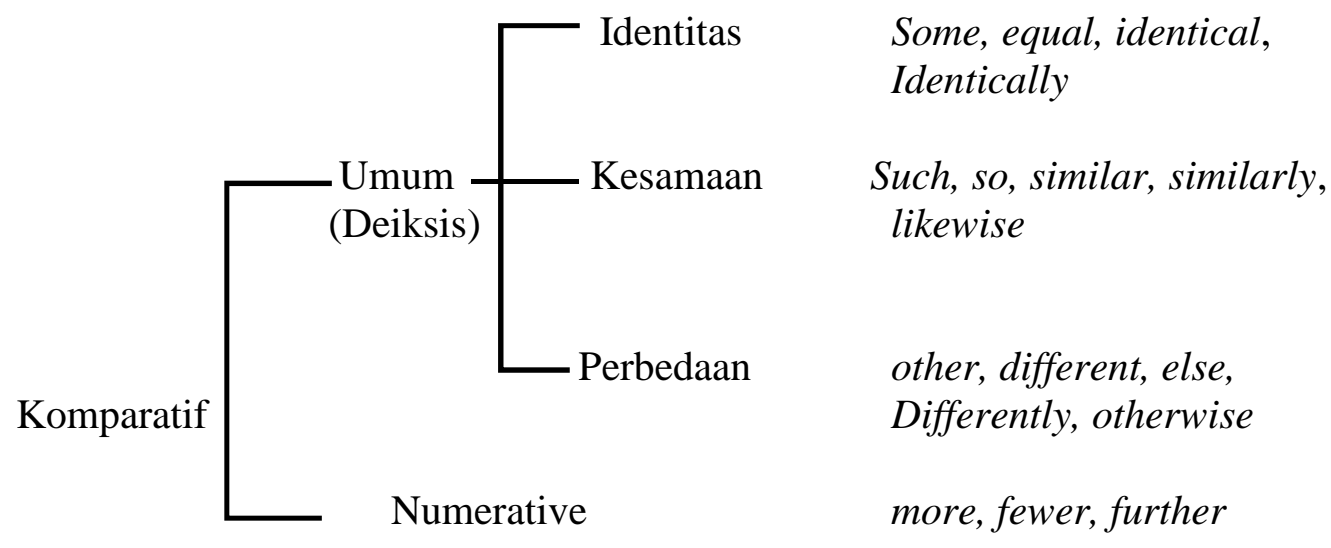




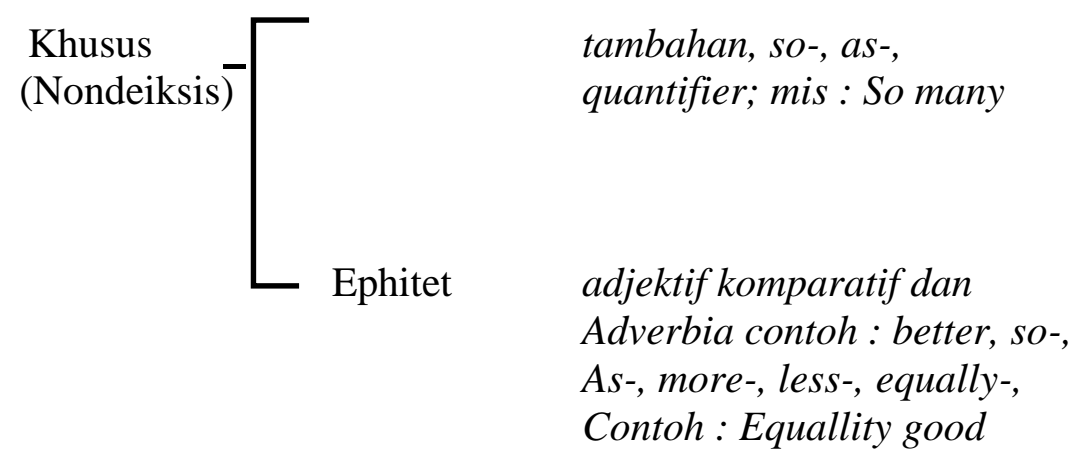

Melalui tiga buah contoh kalimat di bawah ini dapat diketahui penggunaan referen komparatif dalam kalimat dan hal apa saja yang dibandingkan oleh referen-referen komparatif tersebut.

a. We have received exactly the same report as was submitted two months ago.

$b$. There are other qualities than conviviality needed for this job.

c. Find a number equal to the square of the sum of its digits.

Pada kalimat pertama (a), referen komparatifnya as dan referennya adalah [the one that was submitted two months ago. Than pada kalimat kedua (b) membandingkan other qualities dengan referen conviviality, sedangkan equal pada (c) membandingkan number dengan referen the square of the sum of its digits. Penentuan referen baru dapat ditentukan apabila konteks tuturan sudah diketahui dengan pasti. Makna referensial implisit akan dibiarkan tetap implisit maupun dijadikan eksplisit dalam terjemahan bergantung pada masing-masing sistem bahasa sasaran. Pemahaman makna referan implisit ini berperan penting dalam penerjemahan terutama untuk mencegah terjadinya ambiguitas. Sebagai contoh, apabila kita mendengar istilah kota hujan maka pikiran kita akan langsung mengacu pada kota Bogor yang memang terkenal sering hujan. Dalam konteks kalimat banjir melanda kota hujan informasi Bogor sebagai acuan dari kata kota hujan dibuat implisit. Hal ini dapat dilakukan karena informasi ini sudah banyak dikenal orang. Untuk kasus tertentu, misalnya untuk memberikan informasi ini kepada pembaca yang bukan orang Indonesia, kalimat tadi dapat saja dibuat eksplisit menjadi banjir melanda Bogor yang terkenal sebagai kota hujan.

\section{Makna Organisasional Implisit}

Aminuddin (1985: 88) menyatakan bahwa makna organisasional adalah Makna yang timbul akibat adanya peristiwa gramatikal, baik antara imbuhan dengan kata dasar maupun antara kata dengan kata atau frase dengan frase disebut organisasional.

Sebuah kalimat dibentuk dari kata-kata tadi dalam sebuah kesatuan kalimat itulah yang dimaksud dengan makna organisasional. Terkadang makna organisasional dibiarkan implisit, sehingga kita mengenal adanya makna organisasional (kontekstual) implisit. Untuk memperjelas definisi di atas, ada baiknya kita memperhatikan kalimatkalimat berikut. Kalimat kota Bogor didirikan pada tahun 1620 dipakai untuk menempatkan kota Bogor sebagai pokok pembicaraan. Untuk melakukan hal ini, informasi mengenai siapa yang mendirikannya dibuat implisit. Apabila pokok pembicaraannya adalah pendiri kota Bogor maka kalimat tadi dapat dieksplisitkan menjadi Prabu Siliwangi mendirikan kota Bogor pada tahun 1620. Pengimplisitan makna-makna organisasional dapat diwujudkan ke dalam tiga bentukan kalimat, yaitu: kalimat elipsis, kalimat pasif dan penggunaan kata 
substitusi dalam kalimat (Larson, 1984: 40-41). Elipsis adalah penghilangan unsur kalimat, walaupun demikian struktur kalimat elipsis tetap memenuhi aturan pola kalimat yang berlaku. Dalam kalimat pasif seringkali pelaku dari kalimat tersebut diimplisitkan, hal ini disebabkan pelaku dalam kalimat pasif bukanlah pokok pembicaraan. Penggunaan kata substitusi dalam kalimat biasanya disebabkan untuk menghindari pengulangan atau redundan. Ketiga bentukan ini menyebabkan timbulnya makna implisit organisasional. Walaupun secara struktur kalimatnya tidak utuh namun pengertian yang dibawa tetap utuh.

\section{a. Makna Situasional Implisit Akibat Faktor Budaya}

Suatu teks mungkin sama sekali tidak dimengerti oleh orang yang tidak mengetahui latar belakang budaya penutur karena di dalamnya terdapat begitu banyak makna situasional yang diimplisitkan. Apabila penutur dan penanggap memiliki latar belakang budaya yang sama maka akan banyak terdapat istilah yang berhubungan dengan budaya yang dibiarkan implisit. Hal ini disebabkan oleh adanya pengetahuan yang telah dimiliki bersama. Makna situasional implisit yang disebabkan oleh faktor budaya akan menjadi batu sandungan yang cukup besar jika penanggap memiliki latar belakang budaya yang sangat berbeda dari penutur. Oleh karena itu, dalam penerjemahannya makna implisit ini harus dieksplisitkan agar pesan penutur dapat tersampaikan dengan baik, kecuali jika istilah yang dipakai sudah tidak asing lagi bagi penanggap. Untuk lebih jelasnya perhatikan contoh kalimat berikut ini: "I really really love Jodie Foster in The Silence of The Lambs." The Silence of The Lambs adalah film Amerika yang cukup terkenal dan Jodie Foster adalah artis wanita pemeran utama film tersebut. Untuk orang yang tidak mengenal Jodie Foster atau The Silence of The Lambs, kalimat di atas tidak memiliki arti apa-apa bahkan cenderung membingungkan. Namun bagi sebagian orang Indonesia yang akrab dengan film-film Amerika kalimat di atas telah cukup jelas, karena mereka tahu bahwa Jodie Foster adalah seorang artis wanita terkemuka dan The Silence of The Lambs adalah salah satu filmnya.

\section{b. Makna Situasional Implisit karena Gerakan Isyarat saat Ujaran}

Kadang-kadang suatu kata atau kalimat baru bisa dipahami dengan baik apabila didukung oleh gerakan isyarat yang dilakukan penutur pada saat ujaran terjadi. Hal inilah yang melatarbelakangi terjadinya makna implisit yang disebabkan oleh gerakan isyarat. Untuk lebih jelasnya dapat dilihat pada contoh kalimat berikut ini: James pointed to his car and said, "Get in. I'll drive you home." Dari contoh kalimat di atas terlihat pada kalimat pertama ada gerakan yang dilakukan oleh penutur, yaitu gerakan menunjuk ke arah mobilnya. Melalui gerakan ini, lebih jelas bahwa yang dimaksud oleh kata get in pada kalimat berikutnya adalah get in my car.

\section{1) Makna Situasional Implisit yang Disebabkan Waktu dan Tempat Terjadinya Komunikasi}

Kadang-kadang suatu kalimat baru dapat dimengerti maknanya apabila dihubungkan dengan pengertian lain yang dibawa oleh tempat atau waktu pada saat terjadinya ujaran. Misalnya saja kata masuk! dapat memiliki arti bermacam-macam tergantung tempat 
pengucapannya. Di dalam kelas kata masuk dapat berarti hadir, sedangkan kata yang sama dapat berarti di dalam garis pada saat bermain bulutangkis di lapangan bulutangkis. Waktu terjadinya komunikasi juga dapat menyebabkan timbulnya makna implisit. Misalnya apabila seorang anak pulang ke rumah menjelang tengah malam kemungkinan orang tuanya akan berkata kenapa tidak pulang pagi saja? Padahal tentu saja maksud orang tuanya tidak seperti itu. Ada makna implisit yang terkandung di dalam pernyataan tersebut yang bisa saja berupa imbauan agar anaknya bisa pulang lebih cepat atau bahkan sindiran mengenai kepulangan si anak yang terlalu malam.

\section{2) Makna Situasional Implisit Akibat Hubungan Penutur dan Penanggap}

Hubungan antara penutur dan penanggap sangat mempengaruhi makna yang terkandung di dalam kalimat. Adanya hubungan tertentu antara penutur dan penanggap dapat menyebabkan adanya makna yang diimplisitkan misalnya Budi akan berkata kepada teman sekelasnya Pak Iwan tidak masuk hari ini karena si penanggap telah mengetahui bahwa yang dimaksud dengan Pak Iwan adalah guru IPA mereka. Ketika Budi ingin membicarakan mengenai orang yang sama kepada ibunya, mungkin ia akan berkata Pak Iwan, guru IPA kami, tidak masuk hari ini. Sebagai contoh lain kita akan melihat kalimat yang diucapkan oleh seorang wanita. Kepada suaminya ia berkata Peter sakit flu. Namun ketika ia ingin menyampaikan informasi yang sama kepada dokter, wanita ini akan berkata anak saya, Peter, sakit flu informasi anak saya tidak diperlukan untuk menandakan Peter ketika berbicara kepada suaminya yang tahu benar siapa Peter itu. Makna yang terdapat dalam sebuah teks bisa digolongkan ke dalam berbagai jenis, salah satunya adalah makna implisit. Sifat dari makna implisit yang tidak ditampilkan menjadikan keberadaannya terkadang sulit untuk dilihat dan dimengerti secara sambil lalu. Namun makna implisit merupakan bagian dari teks tersebut sehingga peranannya dalam menjaga kesatuan dan keutuhan teks tidak kalah penting dari komponen makna yang lain

Kesimpulan dari makna implisit yaitu Larson membagi makna implisit menjadi tiga macam yaitu: makna referensial implisit, makna organisasional implisit dan makna implisit situasional (1984: 34--37). Analisis akan dibagi berdasarkan ketiga macam makna implisit ini.

Makna referensial implisit dapat ditemukan dalam kalimat yang memiliki pronomina persona, pronomina posesif, dan pronomina refleksif terutama yang dalam kata-kata seperti it, he, she, they,. Juga ditemukan dalam kata demonstratif seperti this atau that. Artikel the juga merupakan salah satu kata yang memiliki makna implisit, demikian pula halnya dengan kata-kata komparatif seperti some, most, different, dan more.

Kalimat yang mengandung makna implisit organisasional dapat ditemukan dalam susunan kalimat elipsis dan kalimat pasif sistem bahasa sumber. Selain itu dapat juga ditemukan dalam kalimat yang memiliki kata substitusi seperti one, did, so, do, dan not.

Sedangkan makna situasional implisit ditemukan dalam situasi percakapan. Situasi yang dimaksud adalah hubungan antara penutur dan penanggap, latar belakang budaya, tempat berlakunya proses komunikasi, waktu terjadinya ujaran, usia dan jenis kelamin, situasi sosial penutur dan penanggap, praduga yang muncul dalam situasi berkomunikasi dan gerakan isyarat yang terjadi selama proses komunikasi berlangsung. Dalam skripsi ini faktor-faktor yang cukup banyak tadi akan dibatasi sehingga analisis makna 
situasional implisit terdiri dari empat bagian, yaitu makna implisit yang timbul akibat faktor budaya, gerakan isyarat, waktu dan tempat komunikasi, serta hubungan penutur dan penanggap.

\section{Kerangka Berpikir}

Menurut landasan teori di atas, pada dasarnya makna implisit dibagi menjadi tiga bagian : makna implisit refrensial, makna implisit organisasional, makna implisit situasional. Dengan beragamnya makna implisit kita dapat menjawab pertanyaan dengan mudah karena dapat membagi menjadi tiga bagian. Oleh karena itu kita dapat dengan mudah menganalisis suatu masalah yang berhubungan dengan makna, apalagi makna implisit. Para penikmat film dan pembaca dapat memberikan pemahaman yang lebih detail. Pemahaman yang lebih detail dalam menganalisa makna juga menuntut keterampilan dalam membaca teks film. Untuk menganalisis penerjemahan makna implisit, penulis mengumpulkan berbagai data dan membahasnya sesuai dengan aturan yang berlaku pada bahasa sasaran sehingga dapat diketahui apakah penerjemahan tersebut telah sesuai dengan aturan yang berlaku pada bahasa sasaran, timbul tidaknya kerancuan dan terjaga tidaknya keutuhan teks asli.

\section{METODOLOGI PENELITIAN}

Metode dalam penelitian ini menggunakan metode kualitatif. Metode kualitatif pada dasarnya sama dengan metode hermeneutika. Artinya, baik metode hermeneutika, kualitatif dan analisis isi, secara keseluruhan memanfaatkan cara-cara penafsiran dengan menyajikanya dalam bentuk deskriptif menurut Kutha (2007: 46). Landasan berfikir metode kualitatif adalah paradigma positivistik Max Weber, Immanuel Kant dan Wilhelm Dilthey (Moleong, 1989: 10 - 11). Sesuai dengan namanya, penelitian kualitatif mempertahankan hakikat nilainilai. Oleh karena itu, penelitian kualiatatif dipertentangkan dengan penelitian kuantitatif yang bersifat bebas nilai. Dalam ilmu sosial sumber datanya adalah masyarakat, data penelitiannya adalah tindakan-tindakan, sedangkan ilmu sastra sumber datanya adalah karya, naskah, data penelitiannya, sebagai data formal adalah kata, kalimat, wacana. Menurut Kutha (2007: 47 - 48) Ciri - ciri terpenting dalam metode kualitatif, sebagai berikut.

1. Memberikan perhatian utama makna pada pesan, sesuai dengan hakikat objek, yaitu sebagai studi kultural.

2. Lebih mengutamakan proses dibandingkan dengan hasil penelitian sehingga makna selalu berubah.

3. Tidak ada jarak antara subjek peneliti dengan objek penelitian, subjek peneliti sebagai instrumen utama, sehingga terjadi interaksi langsung di antaranya.

4. Desain dan kerangka penelitian bersifat sementara sebab penelitian bersifat terbuka.

5. Penelitian bersifat alamiah, terjadi dalam konteks sosial budayanya masing-masing.

\section{Pendekatan Penelitian}

Penelitian ini menggunakan pendekatan Objektif, menurut Kutha (2007: 72 - 73), pendekatan objektif merupakan pendekatan yang paling terakhir dibicarakan. Pendekatan ini juga merupakan pendekatan yang terpenting sekaligus memiliki kaitan yang paling erat dengan teori sastra modern, khususnya pendekatan yang menggunakan konsep dasar struktur.

Pendekatan objektif merupakan pendekatan yang terpenting sebab pendekatan apapun yang dilakukan pada dasarnya bertumpu pada karya sastra itu sendiri. Pendekatan objektif dengan demikian memusatkan perhatian semata-mata pada unsur-unsur, yang dikenal dengan 
analisa instrinsik. Konsekuensi logis yang ditimbulkan adalah mengabaikan bahkan menolak segala unsur ekstrinsik, seperti aspek historis, sosiologis, politis dan unsur - unsure sosiokultural lainnya, termasuk biografi. Oleh karena itu, pendekatan objektif juga disebut analisis otonomi, analisis ergocentric, pembacaan mikroskopi.

Dengan adanya penolakan terhadap unsur - unsur yang ada diluarnya, maka masalah mendasar yang harus dipecahkan dalam pendekatan objektif harus dicari dalam citra bahasa, statistika, dan aspek lain yang berfungsi untuk menimbulkan kualitas estetika.

\section{Teknik Penelitian}

Sumber dan jenis data dilihat dari jenis datanya, penelitian ini meupakan kajian pustakaan karena data dan fenomena yang dikaji adalah data tertulis yang diperoleh dari bahan pustaka.

\section{Populasi dan Sampel}

Populasi adalah wilayah generalisasi yang terdiri atas obyek/subyek yang mempunyai kuantitas dan karakteristik tertentu yang ditetapkan oleh peneliti untuk dipelajari dan kemudian ditarik kesimpulannya. Jadi populasi bukan hanya orang, tetapi juga benda-benda alam lain. Populasi juga bukan sekedar jumlah yang ada pada obyek/subyek yang dipelajari, tetapi meliputi seluruh karakteristik/sifat yang dimiliki oleh subjek atau objek itu.

Misalnya akan dilakukan penelitian di lembaga $\mathrm{X}$, maka lembaga $\mathrm{X}$ ini merupakan populasi. Lembaga X mempunyai sejumlah orang/subyek dan obyek yang lain. Hal ini berarti populasi dalam arti jumlah/kuantitas. Tetapi lermbaga $\mathrm{X}$ juga mempunyai karakteristik orang-orangnya, misalnya motivasi kerjanya, disiplin kerjanya, kepemimpinannya, iklim organisasinya dan lainlain. Juga mempunyai karakteristik objek yang lain, misalnya kebijakan, prosedur kerja, tata ruang produk yang dihasilkan dan lain-lain. Yang terakhir berarti populasi dalam arti karakteristik. Satu orangpun dapat digunakan sebagai populasi, karena satu orang mempunyai berbagai karakteristik, misalnya gaya bicaranya, disiplin pribadi, hobi, cara bergaul, kepemimpinannya dan lain-lain. Misalnya akan melakukan penelitian tentang kepemimpinan presiden Y, maka kepemimpinan itu merupakan sampel dari semua karakteristik yang dimiliki presiden Y. Jadi sampel adalah bagian dari jumlah dan karakteristik yang dimiliki oleh populasi (Sugiyono, 2002: 57 ).

Populasi penelitian atau sumber data berasal dari film Pursuit of Happiness karya Gabriele Muccino berdurasi 01:57:17 dan sample penelitian ini merupakan keseluruhan pembicaraan yang terdapat makna implisit.

\section{Instrumen Penelitian}

Sebagai mana lazimnya penelitian kualitatif yang menggunakan manusia sebagai alat pengumpul data (Modeong, 1991: 4). Instrumen utama dalam penelitian adalah penulisan sendiri untuk pencatatan dengan perekaman data - data penulis menggunakan table - table yang diberi label sesuai dengan jenis unsure instrinsik yang akan dianalisa.

\section{Teknik Pencatatan Data}

Berdasarkan instrumen penelitian yang penulis gunakan maka penulis menggunakan teknik pencatatan dalam menganalisa makna implisit :

1. Mencari buku referensi dan Film. 
2. Menonton dan memahami Film.

3. Memahami makna implisit secara menyeluruh.

4. Menetapkan permasalahan dalam film dan refernsi.

5. Mengkaji makna implisit dalam film Pursuit of Happiness.

\section{Teknik Pemeriksaan Keabsahan Data}

Penelitian ini menggunakan dua jenis teknik keabsahan data yaitu, dengan eksploratif analisis dan deskriptif eksploratif digunakan dalam menonton dan memahami film secara intensif untuk menjaring data yang dibutuhkan. Deskriptif analisis digunakan dalam mengkaji, mengeksploratifkan dan mensistematiskan data yang telah terjaring. Teknik deskriptif analisis juga digunakan untuk mengetahui hubungan antar unsur instrinsik film dengan unsur ekstrensik tertentu

\section{PEMBAHASAN}

Dalam bab ini akan menguraikan penelitian dan pembahasan mengenai makna implisit dalam sebuah film.

\section{A. Makna Referensial Implisit \\ 1. Referen Persona Implisit Diterjemahkan Secara Eksplisit}

(PoHE/06:29)

(PoHE adalah Pursuit of Happiness subtitle english dan 06:29 adalah durasi waktu percakapan berlangsung ) contoh kalimat You see that car? The one with pretty yellow shoe on it ? terjadi ketika durasi waktu pembicaraan saat menit ke 6 dan detik ke 29.

\begin{tabular}{|l|l|}
\hline \multicolumn{1}{|c|}{ Data 1a } & \multicolumn{1}{|c|}{ Data 1b } \\
\hline $\begin{array}{l}\text { You see that car? the one with pretty } \\
\text { yellow shoe on it? }\end{array}$ & $\begin{array}{l}\text { Kau lihat mobil itu ? dengan sepatu } \\
\text { kuning diatas rodanya ? }\end{array}$ \\
\hline
\end{tabular}

Dalam data yang di atas terdapat pengimplisitan dalam pretty yellow shoe, karena tidak mungkin sebuah mobil memakai sepatu dirodanya. Ini merupakan pengimplisitan dari alat tilang polisi. Dalam hal itu it di data mengimplisitkan makna persona yang menjelaskan pretty yellow shoes

(PoHE/06:33)

\begin{tabular}{|l|l|}
\hline \multicolumn{1}{|c|}{ Data 2a } & \multicolumn{1}{c|}{ Data 2b } \\
\hline $\begin{array}{l}\text { You see that car? The one with pretty } \\
\text { yellow shoe on it ?That's mine. }\end{array}$ & $\begin{array}{l}\text { Kau lihat mobil itu ? Dengan sepatu } \\
\text { kuning diatas rodanya? Itu mobilku }\end{array}$ \\
\hline
\end{tabular}

Dalam data pertama sedang membicarakan mobil yang di parkir, dikalimat selanjutnya mine menggantikan mobil dalam kalimat sebelumnya. Jadi mine disini menjelaskan mobilnya.

(PoHE/11:50)

\begin{tabular}{l|l} 
Data 3a & Data 3b \\
\hline
\end{tabular}




\begin{tabular}{|l|l|}
\hline $\begin{array}{l}\text { I got three of them before the damn } \\
\text { office is even open. }\end{array}$ & $\begin{array}{l}\text { Aku punya tiga janji bahkan sebelum } \\
\text { kantornya buka. }\end{array}$ \\
\hline
\end{tabular}

Referen persona dalam kalimat I got three of them before the damn office is even open adalah Them yang dimana terjadi pengimplisitan yang mengandung arti janji, karena janjinya lebih dari dua jadi menggunakan Them. Disini penerjemah menerjemahkan secara eksplisit agar tidak ada kesalahan makna dan arti dari kalimat tersebut.

(PoHE/13:51)

\begin{tabular}{|c|c|}
\hline Data $4 a$ & Data $4 b$ \\
\hline $\begin{array}{l}\text { Jay Twistle in the main office. He } \\
\text { oversees witter resources }\end{array}$ & $\begin{array}{l}\text { Temui Jay Twistle di kantor utama. } \\
\text { Dia yang mengawasi SDM }\end{array}$ \\
\hline
\end{tabular}

Dalam 2 kalimat di atas terdapat referen persona yang menjelaskan subjek utama dalam kalimat pertama, dalam kalimat ke dua He oversees witter resources, he menjelaskan Jay Twistle. He merupaka referen persona yang menjelaskan dia laki - laki.

(PoHE/07:26)

\begin{tabular}{|l|l|}
\hline \multicolumn{1}{|c|}{ Data 5a } & \multicolumn{1}{|c|}{ Data 5b } \\
\hline $\begin{array}{l}\text { From who ?. Cynthia from work. It is } \\
\text { for adult. Chris can't use it. She didn't } \\
\text { know }\end{array}$ & $\begin{array}{l}\text { Itu untuk orang dewasa. Tapi Chris } \\
\text { belum boleh mamainkannya. Dia tidak } \\
\text { tahu. }\end{array}$ \\
\hline
\end{tabular}

Pada data di atas terjadi pemngimplisitan pelaku yaitu referen persona she pada kalimat terakhir pada data di atas yang mengandung makna orang ketiga tunggal perempuan. She di sini menjelaskan Cynthia bukan menjelaskan Chris. Walaupun arti dalam kalimat itu diimplisitkan menjadi dia tetapi dalam kalimat sebelumnya sedang membahas Cynthia.

\section{Referen Persona Implisit Diterjemahkan Menjadi Referen Persona (PoHE/05:44)}

\begin{tabular}{|l|l|}
\hline \multicolumn{1}{|c|}{ Data 6a } & \multicolumn{1}{|c|}{ Data 6b } \\
\hline $\begin{array}{l}\text { Thank you for the opportunity to } \\
\text { discuss it with you. I appreciated it. }\end{array}$ & $\begin{array}{l}\text { Terima kasih banyak untuk kesempatan } \\
\text { mendiskusikannya. Aku hargai itu. }\end{array}$ \\
\hline
\end{tabular}

Dalam kalimat Thank you for the opportunity to discuss it with you. Dalam kalimat ini terdapat referen persona implisit dalam kata it. Kata it tidak dijelaskan dalam kalimat sebelumnya secara eksplisit tetapi menjadi referen persona dalam bahasa Indonesia. Arti kata it dalam bahasa Indonesia di artikan -nya.

(PoHE/07:21) 


\begin{tabular}{|l|l|}
\hline \multicolumn{1}{|c|}{ Data 7a } & \multicolumn{1}{c|}{ Data 7b } \\
\hline $\begin{array}{l}\text { What is this ? } \\
\text { It's a gift for Christoper. }\end{array}$ & $\begin{array}{l}\text { Apa ini ? } \\
\text { Itu hadiah untuk Christoper. }\end{array}$ \\
\hline
\end{tabular}

Dalam kalimat It's a gift for Christoper, dijelakan sacara visual tetapi tidak dijelaskan bahwa itu apa. Dalam kalimat ini it digantikan dengan itu bukan dijelaskan dengan secara eksplisit melalui nama atau sebagainya karena kalimat sebelumnya tidak menjelaskan itu.

(PoHE/07:26)

\begin{tabular}{|l|l|}
\hline \multicolumn{1}{|c|}{ Data 8a } & \multicolumn{1}{|c|}{ Data 8b } \\
\hline $\begin{array}{l}\text { From who ?. Cynthia from work. It is } \\
\text { for adult. Chris can't use it. She didn't } \\
\text { know }\end{array}$ & $\begin{array}{l}\text { Itu untuk orang dewasa. Tapi Chris } \\
\text { belum boleh mamainkannya. Dia tidak } \\
\text { tahu. }\end{array}$ \\
\hline
\end{tabular}

Berbeda dengan data sebelumnya bila it dalam data 7, it digantikan dengan itu dalam kalimat ...Chris can't use it. She didn't know digantikan dengan -nya menjadi memainkannya tetapi karena sedang membahas hadiah untuk Christoper yang sedang dimainkan oleh Chris itu menjadi lebih jelas walaupun tidak tahu itu apa.

(PoHE/54:01)

\begin{tabular}{|l|l|}
\hline \multicolumn{1}{|c|}{ Data 9a } & Data 9b \\
\hline Hey dad, I am going pro. & Hey ayah, aku mau jadi profesional. \\
\hline
\end{tabular}

Pada data di atas terdapat referen persona yang mengimplisitkan pelaku tunggal, referen persona terdapat dalam kata $I$ yang diartikan menjadi aku yang dalam kalimat sebelumnya tetapi kalimat ini sangat jelas karena hanya Chris dan Christoper yang bermain basket dan artinya menjadi dapat dimengerti.

(PoHE/10:15)

\begin{tabular}{|c|c|}
\hline Data 10a & Data 10b \\
\hline They all looked sa damn happy to me. & Mereka semua tampak bahagia bagiku. \\
\hline
\end{tabular}

Dalam kalimat di atas terdapat pengimplisitan pelaku jamak terdapat dalam kata They. Kata di atas diartikan menjadi mereka yang dimana tidak dijelaskan dalam kalimat sebelumnya tetapi karena dijelaskan secra visual menjadi lebih jelas yang disebut mereka.

\section{Referen Demonstratif Implisit Diterjemahkan Secara Eksplisit} (PoHE/05:30)

\begin{tabular}{|c|l|}
\hline Data 11a & \multicolumn{1}{|c|}{ Data 11b } \\
\hline He travel in the past with this machine. & $\begin{array}{l}\text { Dia travel ke masa lalu dengan mesin } \\
\text { ini. }\end{array}$ \\
\hline
\end{tabular}


Dalam kalimat He travel in the past with this machine. Dalam hal ini referen persona implisit terdapat dalam kata this. This disini menjelaskan mesin yang dalam kalimat sebelumnya tidak dijelaskan tetapi karena mesinnya ada dalam bagian film jadi sudah dapat dimengerti This ini adalah mesin yang di pegang Chris.

(PoHE/16:23)

\begin{tabular}{|l|l|}
\hline \multicolumn{1}{|c|}{ Data $12 \mathrm{a}$} & \multicolumn{1}{c|}{ Data $12 \mathrm{~b}$} \\
\hline Come back without that, please. & Kembalilah tanpa mesin itu. \\
\hline
\end{tabular}

Dalam kalimat Come back without that, please terjadi pengimplisitan pada referen persona that yang mengandung makna sesuatu, tetapi disini menjelaskan barang yang dibawa oleh Chris Gardner, untuk menghidari ketidakjelasan dalam terjemahannya diartikan sebagai mesin itu. Jadi referen persona dalam artinya diganti dengan makna yang sebenarnya. (PoHE/24:00)

\begin{tabular}{|l|l|}
\hline \multicolumn{1}{|c|}{ Data 13a } & \multicolumn{1}{|c|}{ Data 13b } \\
\hline $\begin{array}{l}\text { We're gonna come out of this, } \\
\text { everything gonna be fine, all right? }\end{array}$ & Kita akan keluar dari masalah ini. \\
$\begin{array}{l}\text { You said that before when I got } \\
\text { pregnant." It'll be fine “. }\end{array}$ & $\begin{array}{l}\text { Kau pernah katakana itu. Waktu ku hamil. } \\
\text { Katamu semua akan baik - baik saja. }\end{array}$ \\
\hline
\end{tabular}

Dalam data 13 terdapat kata that. Dalam hal ini that disini menjelaskan perkataan sebelumnya. That tersebut mengacu kepada everything gonna be fine. Kata tersebut menjelaskan dengan jelas atau secara implisit.

(PoHE/12:11)

\begin{tabular}{|l|l|}
\hline \multicolumn{1}{|c|}{ Data 14a } & \multicolumn{1}{|c|}{ Data 14b } \\
\hline $\begin{array}{l}\text { Just sell what is in your contract. Get } \\
\text { us out of that business. }\end{array}$ & $\begin{array}{l}\text { Jual saja seperti kontrakmu. Dan } \\
\text { keluarkan kita dari bisnis itu. }\end{array}$ \\
\hline
\end{tabular}

Dalam kalimat Just sell what is in your contract. Get us out of that business terdapat referen persona yaitu di kata that yang menjelaskan kata sesudahnya yaitu business. Penerjemah dalam hal ini mengartikan secara eksplisit karena dengan jelas that menjelaskan bisnis yang membuat ini mudah dipahami.

\section{Referen Demonstratif Implisit Diterjemahkan Menjadi Referen Demonstratif} (PoHE/06:23)

\begin{tabular}{|l|l|}
\hline \multicolumn{1}{|c|}{ Data 15a } & \multicolumn{1}{c|}{ Data 15b } \\
\hline $\begin{array}{l}\text { What are you gonna do about that ? } \\
\text { Look, this is what we gotta do. }\end{array}$ & $\begin{array}{l}\text { Apa yang akan kau lakukan soal itu ? } \\
\text { Ini yang akan kita lakukan. }\end{array}$ \\
\hline
\end{tabular}

Dalam kalimat di atas terdapat referen demonstratif pada kalimat look, this is what we gotta do dalam kata this menjelaskan makna demonstratif Karena dalam kalimat sebelumnya tidak dijelaskan jadi penerjemah mengimplisitkan artinya menjadi ini yang sebenarnya artinya masih 
kurang dapat dipahami tetapi melalui bahasa tubuh ketika Chris berbicara kepada linda menjadi lebih mudah dipahami.

(PoHE/11:00)

\begin{tabular}{|l|l|}
\hline \multicolumn{1}{|c|}{ Data 16a } & \multicolumn{1}{|c|}{ Data 16b } \\
\hline I am gonna stop by a brokerage firm & Aku mau mampir ke firma pialang \\
after work. & saham setelah pulang kerja. \\
For What? & Untuk apa? \\
I wanna see about job there. & Aku mau lihat pekerjaan di sana. \\
\hline
\end{tabular}

Dalam kalimat di atas terdapat referen demonstratif yang menjelaskan tentang keadaan tempat. Referen demonstratifnya terdapat dalam kata There yang menjelaskan kalimat sebelumnya yaitu brokerage firm. Penerjemah tidak secara langsung mengartikan there tetapi dapat dipahami dari kalimat sebelumnya yang maknanya mengarah kepada tempat firma pialang saham.

(PoHE/12:13)

\begin{tabular}{|l|l|}
\hline \multicolumn{1}{|c|}{ Data 17a } & \multicolumn{1}{|c|}{ Data 17b } \\
\hline $\begin{array}{l}\text { Do you mind if I live here with you } \\
\text { just for five minutes? }\end{array}$ & $\begin{array}{l}\text { Boleh aku titipkan ini padamu lima } \\
\text { menit saja?. }\end{array}$ \\
\hline
\end{tabular}

Dalam data terdapat referen demonstratif yang menjelaskan keadaan tempat. Dalam data di atas terdapat dalam kata here yang artinya digabungkan oleh penerjemah bersama objek atau kamu walaupun tidak secara pasti dijelaskan melalui kata - kata tempat barang tersebut diletakan disamping objek. Makna tersebut dapat dipahami dengan melihat visual yang sebenarnya.

$(\mathrm{PoH} / 17: 29)$

\begin{tabular}{|l|l|}
\hline \multicolumn{1}{|c|}{ Data 18a } & \multicolumn{1}{|c|}{ Data 18b } \\
\hline $\begin{array}{l}\text { I was smart back then, so they call me } \\
\text { Ten Gallon Head. }\end{array}$ & $\begin{array}{l}\text { Saat itu pandai, jadi mereka } \\
\text { menyebutkan kepala 10 gallon. }\end{array}$ \\
\hline
\end{tabular}

Dalam data diatas terdapat referen demonstratif yang menjelaskan keadaan dalam bentuk waktu. Dalam kalimat I was smart back then, kata then menunjukan referen demonstrative keadaan waktu, penerjemah tidak menerjemahkan secara jelas tetapi secara implisit dan artinya digabungkan menjadi saat itu pandai.

\section{Referen Komparatif Implisit Diterjemahkan Secara Eksplisit} (PoHE/16:56)
Data 19a
Data $19 b$ 


\begin{tabular}{|l|l|}
\hline $\begin{array}{l}\text { That's an adult word to show an anger } \\
\text { and other things. }\end{array}$ & $\begin{array}{l}\text { Itu istilah orang dewasa untuk } \\
\text { menunjukan kemarahan dan hal lain. }\end{array}$ \\
\hline
\end{tabular}

Dalam data 19 terdapat referen komparatif perbedaan yang membedakan 2 hal / kejadian. Dalam kata That's an adult word to show an anger and other things, kata other dalam kalimat tersebut menunjukan referen komparatif dalam hal ini penerjemah mengartikan ....untuk menunjukan kemarahan dan hal lain. Hal lain disini mengarah kepada hal selain marah.

\section{Referen Komparatif Implisit Diterjemahkan Menjadi Referen Komparatif} (PoHE/03:48)

\begin{tabular}{|l|l|}
\hline \multicolumn{1}{|c|}{ Data 20a } & \multicolumn{1}{|c|}{ Data 20b } \\
\hline $\begin{array}{l}\text { For your birthday gift. You know, } \\
\text { you're only getting a couple of things, }\end{array}$ & $\begin{array}{l}\text { Kau tau bila kau mendapatkan } \\
\text { beberapa saja, ok. } \\
\text { right? }\end{array}$ \\
$\begin{array}{l}\text { Ya, hanya untuk dilihat, dipelajari. } \\
\text { better. }\end{array}$ & \begin{tabular}{l} 
Agar aku bisa memilih lebih baik. \\
\hline
\end{tabular}
\end{tabular}

Dalam data ini terdapat referen komparatif yang diterjemahkan menjadi referen komparatif kembali. Ini terdapat dalam kata better yang membandingkan untuk hadiah ulang tahun yang dia inginkan. Kata beter dalam kalimat ini diterjemahkan menjadi memilih lebih baik.

(PoHE/05:55)

\begin{tabular}{|l|l|}
\hline \multicolumn{1}{|c|}{ Data 21a } & \multicolumn{1}{|c|}{ Data 21b } \\
\hline $\begin{array}{l}\text { It gave a slight denser picture than an } \\
\text { x ray for twice the money }\end{array}$ & $\begin{array}{l}\text { Mesin ini memberikan gambaran lebih } \\
\text { padat daripada sinar x. }\end{array}$ \\
\hline
\end{tabular}

Than merupakan salah satu kata yang membandingkan 2 hal atau lebih dalam 1 atau 2 kalimat. Dalam hal ini membandingkan mesin portable bone density scanner dengan mesin x ray. Kata yang membandingkan 2 hal tersebut adalah than dan penerjemah mengartikan dengan lebih padat.

(PoHE/37:37)

\begin{tabular}{|l|l|}
\hline \multicolumn{1}{|c|}{ Data 22a } & \multicolumn{1}{|c|}{ Data 22b } \\
\hline $\begin{array}{l}\text { All right but I just....,I gotta have some } \\
\text { more time. }\end{array}$ & Aku butuh lebih banyak waktu. \\
\hline
\end{tabular}

More merupakan termasuk salah satu referen komparatif numeratif yang berfungsi membandingkan 2 hal. Dalam data di atas kata more membandingkan waktu yang dia dapatkan dengan waktu yang dia butuhkan. Penerjemah mengartikan some more time menjadi lebih banyak waktu.

(PoHE/06:54)
Data 23a
Data 23b 


\begin{tabular}{|c|c|}
\hline $\begin{array}{l}\text { I'd have to say one more to pay off } \\
\text { those tickets under my windshield } \\
\text { wiper. }\end{array}$ & $\begin{array}{l}\text { Dan aku harus menjual satu lagi untuk } \\
\text { membayar surat tilangku. }\end{array}$ \\
\hline
\end{tabular}

Sama seperti data 23 di atas more disini membandingkan 2 hal atau kejadian dalam hal ini data yang di atas di terjemahkan oleh penerjemah satu lagi, kata lagi merupakan perbandingan antara apa yang dia butuhkan dengan yang sudah dia dapat. Dalam data di atas Chris harus menjual 1 lagi untuk membayar surat tilang.

$(\mathrm{PoHE} / 01: 35: 16)$

\begin{tabular}{|l|l|}
\hline \multicolumn{1}{|c|}{ Data 24a } & \multicolumn{1}{|c|}{ Data 24b } \\
\hline $\begin{array}{l}\text { You guys are both looking to retire at } \\
\text { the same time? }\end{array}$ & $\begin{array}{l}\text { Kalian berdua mencari waktu pensiun } \\
\text { yang sama? }\end{array}$ \\
\hline
\end{tabular}

Dalam data 24 terdapat referen komparatif kesamaan dalam kalimat You guys are both looking to retire at the same time, dalam kata same menjelakan referen komparatif kesamaan dalam data di atas terdapat kesamaan dalam waktu pensiun. Penerjemah menerjemahkan retire at same time menjadi wakti pensiun yang sama.

$(\mathrm{PoH} / 08: 50)$

\begin{tabular}{|l|l|}
\hline \multicolumn{2}{|c|}{ Data 25a } \\
$\begin{array}{l}\text { That deficit is lager than the entire } \\
\text { federal budget in 1957. }\end{array}$ & $\begin{array}{l}\text { Dutang ini lebih besar dari pada } \\
\text { anggaran tahun 1957. }\end{array}$ \\
\hline
\end{tabular}

Dalam data 25 terdapat referen komparatif yang membandingkan 2 hal, dalam kaliamt di atas kata Lager than membandingkan 2 hal, antara that deficit dengan the entire federal budget. Perbandingan dengan referen komparatif longer tersebut mengimplisitkan nomina yang kedua menerangkan bahwa nomina yang pertama lebih besar.

\section{B. Makna Organisasional Implisit}

1. Kalimat Elipsis Diterjemahkan Secara Eksplisit

(PoHE/09:51)

\begin{tabular}{|l|l|}
\hline \multicolumn{1}{|c|}{ Data 25a } & \multicolumn{1}{|c|}{ Data 25b } \\
\hline $\begin{array}{l}\text { Had to go to college to be a } \\
\text { stockbroker, huh ? } \\
\text { You don't have to. }\end{array}$ & $\begin{array}{l}\text { Menjadi makelar saham harus masuk } \\
\text { perguruan tinggi. } \\
\text { Tak perlu. }\end{array}$ \\
\hline
\end{tabular}

Dalam kalimat You don't have to pada data 25 mengelipskan verba. Verba yang dielipskan dalam kalimat ini terdapat dalam kalimat sebelumnya yaitu collage. Seharusnya jawabanya yang lengkap you don't have to collage dan arti kalimat sebenarnya yaitu tak perlu tetapi ini mudah untuk dimengerti.

\section{Kalimat Pasif Diterjemahkan Menjadi Kalimat Pasif}


(PoHE/16:39)

\begin{tabular}{|l|l|}
\hline \multicolumn{1}{|c|}{ Data 26a } & \multicolumn{1}{|c|}{ Data 26b } \\
\hline $\begin{array}{l}\text { It was written as P-P-Y, but it was } \\
\text { supposed to be an I in "Happiness" }\end{array}$ & $\begin{array}{l}\text { Ditulis P-P-Y padahal seharusnya dieja } \\
\text { dengan "I" dalam "Happiness" }\end{array}$ \\
\hline
\end{tabular}

Dalam data 26 di atas terdapat 2 kalimat past tense passive voice. Dalam kalimat keduanya objek / pelaku tidak ada sehingga dilakukan terjemahan secara langsung jadi penerjemah mengartikan dit was written as P-P-Y menjadi ditulis P-P-Y. dan but it was supposed to be an I in "happiness" menjadi padahal seharusnya dieja dengan I dalam "Happiness".

(PoHE/14:29)

\begin{tabular}{|l|l|}
\hline \multicolumn{1}{|c|}{ Data 27a } & \multicolumn{2}{|c|}{ Data 27b } \\
\hline $\begin{array}{l}\text { This part of my life is called being } \\
\text { stupid. }\end{array}$ & $\begin{array}{l}\text { Bagian dari hidupku ini disebut } \\
\text { besikap bodoh. }\end{array}$ \\
\hline
\end{tabular}

Dalam hal ini kalimat pasif terdapat dalam kalimat My life is called being stupid. Dalam kalimat ini kalimat pasif iterjemahkan secara Eksplisit karena membutuhkan objek dalam hal ini yang menjadi objek adalah hidupnya si Chris jadi tidak membuat ambigu dari kata bersikap bodoh.

(PoHE/20:57)

\begin{tabular}{|l|l|}
\hline \multicolumn{1}{|c|}{ Data 28a } & \multicolumn{1}{|c|}{ Data 28b } \\
\hline That was my stolen machine & Itu mesin curianku \\
\hline
\end{tabular}

Berbeda dengan data diatas dalam hal ini kalimat pasif disini tidak menjelaskan secara eksplisit, Phrase my stolen machine menjelaskan that dan that disini tidak di jelaskan secara eksplisit dalam kalimat sebelumnya.

\section{Kata Substitusi Diterjemahkan Secara Eksplisit} (PoHE/21:13)

\begin{tabular}{|c|c|}
\hline Data 29a & Data $29 b$ \\
\hline $\begin{array}{l}\text { I spent our entire life savings on these } \\
\text { things. It was such a revolutionary } \\
\text { machine. } \\
\text { So if I lose one, it was like losing a } \\
\text { month's groceries }\end{array}$ & $\begin{array}{l}\text { Aku habiskan tabungan seumur } \\
\text { hidupku untuk mesin - mesin itu. Itu } \\
\text { mesin - mesin revolutioner. } \\
\text { Jadi jika hilang satu seperti kehilangan } \\
\text { belanjaan sebulan }\end{array}$ \\
\hline
\end{tabular}

terdapat kata yang menunjukan kata subtitusi. Dalam kalimat di atas one merupakan kata subtitusi dari mesin mesin revolutioner dari kalimat sebelumnya tatapi penerjemah menerjemahkannya hanya dengan satu tetapi itu sudah dapat dimengerti. 


\section{Kata Substitusi Diterjemahkan Menjadi Kata Substitusi} (PoHE/57:09)

\begin{tabular}{|c|l|}
\hline Data 30a & \multicolumn{1}{|c|}{ Data 30b } \\
\hline Hey, you wanna want one of those? & Hey, kamu mau itu \\
\hline
\end{tabular}

Kalimat you wanna want one of those merupakan kata subtitusi yang dimana tidak dijelaskan secara tulisan tetapi dengan visual karena si Christoper memegang coklat dan Chris bertanya You wanna want of those ?. jadi dalam hal ini one merupakan subtitusi dari coklat yang dipegang Christoper.

(PoHE/01:53:13)

\begin{tabular}{|l|l|}
\hline \multicolumn{1}{|c|}{ Data 31a } & Data 31b \\
\hline Now, That's funny I like that one & Sekarang itu lucu, aku suka itu \\
\hline
\end{tabular}

Kalimat That's funny I like that one, kata one menjelaskan kalimat That funny I like. Penerjemah menerjemahkan one dalam kalimat ini menjadi itu. Dalam kalimat ini one merupakan subtitusi dari pernyataan that's. Walaupun maknnya diimplisitkan masih dapat dimengerti dengan jelas.

\section{(PoHE/06:25)}

\begin{tabular}{|l|l|}
\hline \multicolumn{1}{|c|}{ Data 32a } & Data 32b \\
\hline See, that's all ever I do & Lihat ?, Aku hanya bias sejauh itu. \\
\hline
\end{tabular}

Dalam kata do pada kalimat That's all ever I do mensubtitusi kata sebelumnya yaitu that's tetapi penerjemah tidak menjelaskan secar eksplisit dan tidak juga dijelaskan pada kalimat sebelumnya. Tetapi dalam kalimat itu menjelaskan usaha yang dilakukan oleh Chris.

(PoHE/44:00)

\begin{tabular}{|l|l|}
\hline \multicolumn{1}{|c|}{ Data 33a } & \multicolumn{1}{|c|}{ Data 33b } \\
\hline $\begin{array}{l}\text { Is it dry now ? } \\
\text { I hope so }\end{array}$ & $\begin{array}{l}\text { Apakah sekarang sudah kering } \\
\text { Ku harap sudah }\end{array}$ \\
\hline
\end{tabular}

So merupakan kata subtitusi dalam data 33 di atas so menjelaskan kalimat sebelumnya agar tidak ada ambiguitas dalam kalimat selanjutnya. So disini menjelaskan masalah keadaan tembok sudah kering atau masih basah.

(PoHE/01:18:49)

\begin{tabular}{|l|l|}
\hline \multicolumn{1}{|c|}{ Data 34a } & \multicolumn{1}{c|}{ Data 34b } \\
\hline $\begin{array}{l}\text { I gotta get back to the ‘60s, Man } \\
\text { That's what I wanna do }\end{array}$ & $\begin{array}{l}\text { Aku harus kembali ke 60an, bung } \\
\text { Itu apa yang harus ku lakukan }\end{array}$ \\
\hline
\end{tabular}


Dalam kalimat di atas data 34 terdapat kata subtitusi. Kata subtitusi terdapat dalam kata do dimana do menjelaskan kalimat sebelumnya penerjemah mengartikan menjadi ku lakukan. Lakukan disini merujuk pada kalimat aku harus kembali ke 60an. Jadi do disini dapat dimengerti dengan jelas.

(PoHE/01:27:15)

\begin{tabular}{|l|l|}
\hline \multicolumn{1}{|c|}{ Data 35a } & \multicolumn{1}{c|}{ Data 35b } \\
\hline $\begin{array}{l}\text { Are we save ? } \\
\text { Yeah, I think so }\end{array}$ & $\begin{array}{l}\text { Apa kita aman? } \\
\text { Ya aku aman }\end{array}$ \\
\hline
\end{tabular}

Dalam kalimat dalam data 35 terdapat kata subtitusi yaitu so. Dalam kalimat I think so diartikan penerjemah menjadi kita aman. Kata so mensubtitusi kata save dalam kalimat pertanyaan sebelumnya.

\section{Makna Situasional Implisit}

1. Makna Situasional Implisit Akibat Faktor Budaya Diterjemahkan Menjadi Makna Situasional Akibat Faktor Budaya

(PoHE/14:22)

\begin{tabular}{|l|l|l|}
\hline \multicolumn{2}{|c|}{ Data 36a } & \multicolumn{2}{|c|}{ Data 36b } \\
\hline $\begin{array}{l}\text { Trusting with hippie girl with my } \\
\text { scanner. }\end{array}$ & $\begin{array}{l}\text { Mempercayakan pemindaiku pada } \\
\text { seorang gadis "hipie” }\end{array}$ \\
\hline
\end{tabular}

Pada data di atas terdapat istilah hippie sebagai ungkapan seorang gadis yang mencari hidup dengan menyanyi dengan pakian gaya scotlandia Chris memanggil gadis tersebut dengan hippie. Penerjemah mengartikan hippie dengan hippie karena merupakan panggil seseorang untuk seseorang jadi artinya bias berbeda - beda.

(PoHE/16:48)

\begin{tabular}{|l|l|}
\hline \multicolumn{1}{|c|}{ Data 37a } & Data 37b \\
\hline Is fuck spell right ? & Apakah fuck diejah dengan benar \\
\hline
\end{tabular}

Istilah Fuck merupakan budaya orang asing terutama African American dalam mengungkapkan kekesalan atau rasa marah mereka kepada seseorang dimana seperti Son of Bitch. Istilah tersebut merupakan bukan kata yang layak dipakai dalam pembicaraan. Penerjemah menerjemahkan dengan Fuck kembali karena menghindari kesulitan dalam penafsiran istilah tersebut maka arti kata diimplisitkan.

\section{Makna Situasional Implisit karena Gerakan Isyarat saat Ujaran Diterjemahkan Menjadi Makna Situasional karena Gerakan Isyarat}

(PoHE/01:22:42) 


\begin{tabular}{|l|l|}
\hline \multicolumn{1}{|c|}{ Data 38a } & \multicolumn{1}{|c|}{ Data 38b } \\
\hline $\begin{array}{l}\text { We can't stay here tonight. } \\
\text { Yes we can. Open the door } !\end{array}$ & $\begin{array}{l}\text { Kita tak bisa tinggal disini semalam. } \\
\text { Ya kita bias. Buka pintu ! }\end{array}$ \\
\hline
\end{tabular}

Kalimat perintah Open the door merupakan gerakan Isyarat saat ujaran diterjemahkan menjadi makan Situasional karena gerakan isyarat. Saat kalimat itu terucap Christoper berbicara kepada bapaknya untuk membukakan pintu dengan menunjuk pintu. Kalimat ini merupakan kalimat yang sering diucapkan. Oleh karena itu, penerjemah menerjemahkannya kedalam bahasa Indonesia.

\section{Makna Situasional Implisit yang Disebabkan Waktu dan Tempat Komunikasi Diterjemahkan Menjadi Makna Siuasional yang Disebabkan Waktu dan Tempat Komunikasi}

(PoHE/01:01:16)

\begin{tabular}{|l|l|}
\hline \multicolumn{1}{|c|}{ Data 39a } & \multicolumn{1}{c|}{ Data 39b } \\
\hline $\begin{array}{l}\text { I had an interview at Dean Witter for } \\
\text { an internship and I got it }\end{array}$ & $\begin{array}{l}\text { Aku ikut wawancara magang di Dean } \\
\text { Witter dan aku mendapatkannya. }\end{array}$ \\
\hline
\end{tabular}

Istilah dalam data 38 menggungkapkan bahwa adanya pengimplisitan istilah dalam kalimat I had an interview at Dean Witter for an internship and I got it. Istilah Dean Witter dalam kalimat tersebut menunjukan tempat dimana terjadinya komunikasi. Jadi karena Dean Witter merupakan tempat penerjemah mengartikan tetap menjadi Dean Witter.

\section{Makna Situasional Implisit Akibat Hubungan Penutur dan Penanggap Diterjemahkan Menjadi Makna Situasional Akibat Hubungan Penutur dan Penanggap}

(PoHE/07:26)

\begin{tabular}{|l|l|}
\hline \multicolumn{1}{|c|}{ Data 40a } & \multicolumn{1}{|c|}{ Data 40b } \\
\hline $\begin{array}{l}\text { From who ?. Cynthia from work It is } \\
\text { for adult. Chris can't use it. She didn't } \\
\text { know. }\end{array}$ & $\begin{array}{l}\text { Itu untuk orang dewasa. Tapi Chris } \\
\text { belum boleh mamainkannya. Dia tidak } \\
\text { tahu. }\end{array}$ \\
\hline
\end{tabular}

Dalam kalimat ini ....Chris can't use it. She didn't know terdapat contoh makna implisit situasional yang menjelaskan penutur dengan penanggap. Pada contoh diatas kita dapat mengetahui She adalah kata ganti untuk dia perempuan dan dalam kalimat sebelumnnya juga dijelaskan secara eksplisit dengan nama.

(PoHE/52:37)

\begin{tabular}{|l|l|}
\hline \multicolumn{1}{|c|}{ Data 41a } & \multicolumn{1}{|c|}{ Data 41b } \\
\hline $\begin{array}{l}\text { Yes, I'd like to live a message for Mr. } \\
\text { Jay Twistle }\end{array}$ & $\begin{array}{l}\text { Ya, aku ingin meninggalkan pesan } \\
\text { untuk Mr. Jay Twistle. }\end{array}$ \\
\hline
\end{tabular}


Dalam data di atas terdapat makna implisit hubungan yang ada antara penutur dengan penganggap. Pada contoh di atas terdapat 2 nama antara Mr Jay dengan I. I disini mengacu kepada Chris. Chris memanggil dengan Mr. Jay Twistle karena Chris merupakan pegawai yang magang di perusahaan yang dimana Mr. Jay Menjadi Manager SDM.

(PoHE/01:40:01)

\begin{tabular}{|l|l|}
\hline \multicolumn{1}{|c|}{ Data 42a } & \multicolumn{1}{|c|}{ Data 42b } \\
\hline $\begin{array}{l}\text { Let me run up and grab that for you, } \\
\text { Mr Frohm. }\end{array}$ & $\begin{array}{l}\text { Biar aku lari dan ambil itu untuk mu, } \\
\text { Mr. Frohm. }\end{array}$ \\
\hline
\end{tabular}

Dalam kalimat di atas terdapat pengimplisitan makna antara penutur dengan penganggap disni terdapat 1 nama yaitu Mr Frohm. Nama panggilan tersebut merupakan panggilan Chris kepada Frohm menjadi Mr Frohm karena Mr Frohm merupakan bos dari perusahaan tersebut.

(PoHE/01:02:04)

\begin{tabular}{|l|l|}
\hline \multicolumn{1}{|c|}{ Data 43a } & \multicolumn{1}{|c|}{ Data 43b } \\
\hline Hey, goodbye Mrs. Chu & Hey,Bye Ny Chu \\
\hline
\end{tabular}

Dalam data di atas terdapat pengimplisitan makna antara penutur dengan penganggap. Dalam data terdapat satu nama yaitu Mrs. Chu panggilan tersebut di ucapkan oleh Chris untuk ibu yang menjaga Christoper dalam Day Care karena ibu jadi menggunakan Mrs.

(PoHE/01:35:12)

\begin{tabular}{|l|l|}
\hline \multicolumn{1}{|c|}{ Data 44a } & \multicolumn{1}{|c|}{ Data 44b } \\
\hline $\begin{array}{l}\text { Your wife Martha works at Pac Bell } \\
\text { also, correct? }\end{array}$ & $\begin{array}{l}\text { Istrimu Martha bekerja di Pac Bell } \\
\text { juga, benar? }\end{array}$ \\
\hline
\end{tabular}

Dalam hal ini terdapat pengimplisitan istilah dalam kalimat Your wife Martha works at Pac Bell disini Pac Bell merupakan istilah yang diimplisitkan yang disebabkan oleh tempat. Penerjemah menerjemahkan Pac Bell tetep menjadi Pac Bell karena Pac Bell menunjukan tempat dimana Martha bekerja.

\section{PENUTUP}

\section{Kesimpulan}

Dari hasil analisis makna implisit merupakan makna yang tidak ditampilkan tetapi merupakan bagian dari pembicaraan atau maksud yang ingin disampaikan. Menurut Halliday dan Hasan (1976: 30) Makna implisit digolongkan dalam tiga bagian yaitu makna referensial implisit, makna organisasional implisit dan makna situasional implisit. Makna implisit referensial terbagi menjadi tiga yaitu : referen personal, referen demonstratif dan referen komparatif. Makna implisit organisasional terbagi menjadi tiga yaitu : makna implisit kata 
subtitusi, kalimat eclips dan kalimat pasif. Makna implisit situasional terbagi menjadi makna situasional implisit akibat faktor budaya, Makna situasional implisit karena gerakan isyarat saat ujaran, makna situasional implisit yang disebabkan waktu dan tempat terjadinya komunikasi, makna situasional akibat hubungan penutur dengan penganggap. Makna implisit harus dieksplisitkan apabila makna tersebut dapat menimbulkan ketidak jelasan atau apabila diperlukan penyesuaian dengan tujuan penyampaian pesan yang lebih baik tetapi makna implisit sedapat mungkin dibiarkan tetap implisit apabila sudah sesuai dengan aturan yang berlaku pada bahasa sasaran, hal ini bertujuan untuk menjaga gaya penulisan pengarang.

Berdasarkan hasil analisis makna implisit dalam film Pursuit of Happiness karya Gabriele Muccino. Makna implisit referensial merupakan data terbanyak dalam penelitian ini dikarenakan banyak dialog yang menggunakan makna tersebut dan dalam menerjemahkannya makna implisit referensial mudah dimengerti dan dipahami maksud yang ingin disampaikan oleh penulis.

Penyajian makna implisit dalam film Pursuit of Happiness tidak begitu membingungkan penonton karena dalam film ini dialog yang dibangun tidak begitu banyak tokoh hanya beberapa saja seperti Chris dengan Christoper dan Chris dengan Linda menyebabkan pemakaian makna implisit tidak begitu dalam dan melebar sehingga dengan mudah dapat penonton mengartikannya.

\section{Implikasi}

Berdasarkan Cerita dan kesimpulan penelitian yang telah dilakukan terdapat beberapa implikasi yang kaitannya dengan pendidikan :

1. Percaya Diri dan yakin dalam menggapai cita - cita

2. Berani Menggambil keputusan

3. Mendidik dengan bahasa yang baik dan benar

\section{Saran}

Ada beberapa saran yang ingin disampaikan terkait dengan hasil penelitian ini. Pertama, dalam meneliti suatu film kita harus sudah memahami alur film tersebut seperti apa agar memudahkan kita dalam menganalisa unsur instrinsik dalam suatu film. Kedua, referensi dalam landasan teori diperkuat agar dapat menganalisa dengan baik dan mempunyai batasan dalam menganalisa. Ketiga, luangkan waktu yang cukup dalam menganalisa karena dalam menganalisa dapat berpuluh - puluh kali menonton film yang sama. Keempat, penelitian ini hanya membatasi wilayah kajian pada makna yang ada dalam pembicaraan dalam film. 


\section{DAFTAR PUSTAKA}

Aminuddin, 1985, Semantik: Pengantar Studi Tentang Makna, Bandung: Sinar.

Halliday, M.A.K dan Ruqaiya Hasan, 1976, Cohesion In English, London: Edward Arnorld.

Pateda, Mansoer, Drs.1989. Semantik Leksikal .Flores: Nusa Indah.

Parera, J.D. 2004. Teori Semantik. Jakarta: Erlangga.

Kutha Ratna, Nyoman, Prof. 2007. Teori, Metode dan Teknik Penelitian Sastra. Yogyakarta: Pustaka pelajar.

Keraf, Gorys, 1985. Diksi dan Gaya Bahasa, Jakarta: Gramedia.

Kridalaksana, Harimurti, 1993, Kamus Linguistik. Jakarta;Gramedia.

Kridalaksana, Harimurti, 1993, Kamus Linguistik. Jakarta: Gramedia.

Larson, Mildred L., 1984, Meaning-Based Translation : A Guide to Cross Language Equivalence, USA: University of America.

http://id.wikipedia.org/wiki/Film (diakses tanggal 18 Juni 2014).

http://en.wikipedia.org/wiki/Film (diakses tanggal 18 Juni 2014). 